\title{
Regulation of the Transfer of TI Plasmids of Agrobacterium tumefaciens
}

\author{
By P. J. J. HOOYKAAS, C. ROOBOL AND R. A. SCHILPEROORT \\ Department of Biochemistry, State University, Leiden, The Netherlands
}

(Received 25 April 1978; revised 1 July 1978)

Octopine-utilizing agrobacteria could be distinguished from non-utilizers on a solid medium containing octopine as the only added nitrogen source if a $\mathrm{pH}$ indicator such as bromothymolblue were present. On green bromothymolblue plates, octopine-utilizing strains formed orange-yellow colonies, while those of non-utilizers were translucent. Strains could be tested for utilization of other nitrogen sources such as nopaline by substituting these for octopine in the same medium.

Using bromothymolblue plates, it was found that TI plasmids of octopine-utilizing strains of Agrobacterium tumefaciens were transferable in the presence of octopine, octopinic acid or lysopine, but not in the presence of the analogues nor-octopine, homo-octopine or desmethylhomo-octopine. Transfer in the presence of 'inducer' was not detected when bacteria were mated at $37{ }^{\circ} \mathrm{C}$ instead of $29{ }^{\circ} \mathrm{C}$, or when either methionine, cysteine or cystine was present in the mating medium. Mutant plasmids were obtained that were conjugative in the absence of an inducer; these were insensitive to methionine and cysteine but, like the wild-type plasmid, were thermosensitive for transfer.

The TI plasmid of an octopine-utilizing strain was introduced into a strain that carried a deleted nopaline TI plasmid. These plasmids were found to be compatible. The properties of this transconjugant showed that the octopine oxidase does not accept nopaline as a substrate. Tumours induced on Kalanchoë daigremontiana by this bacterium were rough and contained octopine. Exclusion of phage S18 was found to be a marker specific for the TI(Kerr14) plasmid.

\section{INTRODUCTION}

Virulent Agrobacterium tumefaciens strains carry large plasmids (TI plasmids) that are essential for the oncogenic properties of the bacteria (Zaenen et al., 1974). The mechanism whereby agrobacteria transform normal cells into tumour cells is unknown. However, recently it was shown that a small fragment of the TI plasmid is present in transformed plant cells (Chilton et al., 1977) and is transcribed into RNA (Drummond et al., 1977). How this bacterial DNA enters the plant cell is unknown. Since tumour induction can be inhibited by preventing attachment of the virulent bacteria to the plant cells (Schilperoort, 1969; Lippincott \& Lippincott, 1969; Lippincott et al., 1977; Whatley et al., 1976), it is possible that DNA is transferred from the bacteria to plant cells by a conjugation-like mechanism. It is well known that TI plasmids can act as conjugative plasmids in crown gall tumours, i.e. avirulent Agrobacterium strains can become oncogenic by acquisition of the TI plasmid from a virulent strain in mixed infections of plants (van Larebeke et al., 1975; Watson et al., 1975; Kerr et al., 1977). Ex planta, however, transfer of TI plasmids was not observed, although they could be mobilized by the R plasmid RP4 (Bomhoff et al., 1976; Chilton et al., 1976; Hooykaas et al., 1977; van Larebeke et al., 1977). More recent studies have now shown that TI plasmids can act as conjugative plasmids ex planta if the bacteria are incubated 
on a synthetic medium containing high concentrations of octopine or nopaline (Kerr et al., 1977; Genetello et al., 1977).

Tumours induced by octopine-utilizing strains synthesize octopine and those induced by nopaline-utilizing strains synthesize nopaline (Petit et al., 1970; Bomhoff et al., 1976; Montoya et al., 1977) which could explain the transfer of TI plasmids in planta. Avirulent strains that had acquired a TI plasmid in planta could be isolated 3 weeks after mixed infection of plants (Kerr, 1971), probably coinciding with the accumulation of octopine or nopaline. Since octopine and nopaline have never been detected in normal plant tissue (Bomhoff, 1974; Kemp, 1976; Gordon et al., 1978) and transfer of TI plasmids between bacteria has only been demonstrated in the presence of these guanidines, it is likely that the mechanism of transfer of TI plasmid DNA to plant cells differs from the bacteriumbacterium conjugation mechanism. It remains, however, possible that there are other plant cell metabolites which may enable the TI plasmids to act as sex factors. To clarify the situation we have studied the effect of various normal cell metabolites on the bacterium-bacterium transfer of TI plasmids.

The only useful genetical marker on TI plasmids is the ability to degrade either octopine or nopaline. Growth on media containing octopine as the sole carbon source is poor. Unfortunately it is also impossible to use a medium with octopine as a sole nitrogen source as selective medium, since nitrogen-containing compounds present in agar permit growth of agrobacteria. Washing agar is time-consuming and does not always give satisfactory results. It is possible to use mutant recipients that require arginine for growth, as was done by Chilton et al. (1976); octopine then supplies the arginine-requirement for octopine-degrading bacteria. However, Arg- strains must be made and auxotrophic mutants may give results different from those with prototrophic strains as recipients.

In this paper we describe a simple solid medium that can be used to distinguish octopineutilizing strains from non-utilizers. We have used this medium to study the transfer of TI plasmids per se and transfer mediated by $\mathbf{R}$ plasmids.

\section{METHODS}

Strains. These are listed in Table 1. Strains B6s3, Kerr14, Kerr14R1, LBA288 and LBA661 were obtained from Dr J. Schell (Gent, Belgium) and strain c58 was from Dr E. Nester (Seattle, U.S.A.); all other strains were isolated in our laboratory. Phage LPB51 was isolated from soil; other phages were provided by $\mathrm{Dr}$ J. Schell (S1, S2, S3, S5, S6, S18, AP1 and U5).

Media. Minimal medium (MM) contained $\left(\mathrm{g} \mathrm{l}^{-1}\right): \mathrm{K}_{2} \mathrm{HPO}_{4}, 2 \cdot 05 ; \mathrm{KH}_{2} \mathrm{PO}_{4}, 1 \cdot 45 ; \mathrm{NaCl}, 0 \cdot 15$; $\mathrm{MgSO}_{4} .7 \mathrm{H}_{2} \mathrm{O}, 0.50 ; \mathrm{CaCl}_{2} .6 \mathrm{H}_{2} \mathrm{O}, 0 \cdot 1 ; \mathrm{FeSO}_{4} .7 \mathrm{H}_{2} \mathrm{O}, 0.0025 ;\left(\mathrm{NH}_{4}\right)_{2} \mathrm{SO}_{4}, 0.5$; and glucose, $2 \cdot 0$. Rich media NB and LC were as described by Hooykas et al. (1977). Bromothymolblue indicator medium (BTB) contained (g l-1): $\mathrm{K}_{2} \mathrm{HPO}_{4}, 0.09 ; \mathrm{NaCl}, 0 \cdot 15 ; \mathrm{MgSO}_{4} .7 \mathrm{H}_{2} \mathrm{O}, 0.50 ; \mathrm{CaCl}_{2} .6 \mathrm{H}_{2} \mathrm{O}, 0.1 ;$ glucose, $2 \cdot 0$; bromothymolblue, $0 \cdot 15$; and (as nitrogen source) octopine, $0 \cdot 1$, unless otherwise stated. The $\mathrm{pH}$ was adjusted with $\mathrm{NaOH}$ to 7 to 8 . Media were solidifi ed with $1 \cdot 8 \%$ (w/v) Difco Bacto-agar.

Plasmid transfer. Strains grown overnight on NB were diluted 1:20 with the same medium and incubated for a further 4 to $5 \mathrm{~h}$ in a reciprocal shaker. The bacteria were then sedimented and washed with $0.9 \%(\mathrm{w} / \mathrm{v})$ $\mathrm{NaCl}$. A mixture of equal numbers of donor and recipient bacteria was deposited on a membrane filter ( $47 \mathrm{~mm}$ diam.; $0.45 \mu \mathrm{m}$ pore size) by filtration or by spotting with a pipette. Filters were incubated for $32 \mathrm{~h}$ on the desired medium. When required, octopine, nopaline, lysopine, octopinic acid, nor-octopine, homooctopine or desmethylhomo-octopine (structural formulae in Fig. 1) was added to a final concentration of $100 \mathrm{mg}^{-1}$ (unless otherwise stated); other amino acids were added to a final concentration of $50 \mathrm{mg} \mathrm{1}^{-1}$. Organic acids such as pyruvate and citrate were incorporated in the medium at $2 \mathrm{~g} \mathrm{l}^{-1}$. After mating, the bacteria were resuspended in $5 \mathrm{ml} 0.9 \% \mathrm{NaCl}$ and dilutions were plated on BTB medium, containing rifampicin at $100 \mathrm{mg}^{-1}$ to prevent growth of donor bacteria.

Phage sensitivity, agrocin sensitivity, and utilization of octopine and nopaline were tested as described previously (Hooykaas et al., 1977).

BL-test for the production of 3-ketoglycosides was as described by Bernaerts \& De Ley (1963).

Assay for virulence. Tumours were induced on stems of Kalanchoë daigremontiana (Hamet \& Perrier), Nicotiana tabacum var. White Burley and Helianthus annuus var. giganteus as described previously (Schilperoort, 1969; Bomhoff et al., 1976; Hooykaas et al., 1977). 
Transfer of TI plasmids of A. tumefaciens
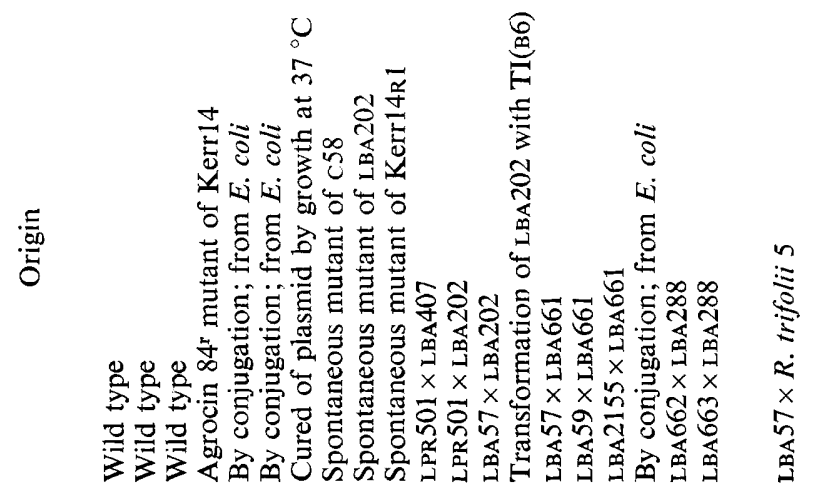

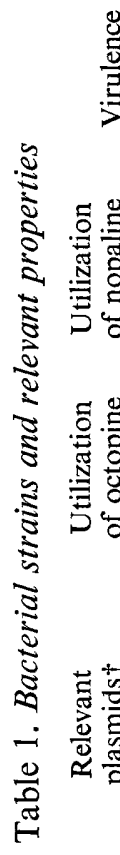

$\frac{8}{2}$

$\hat{\widehat{\hat{\bar{c}}}}$

记

章。

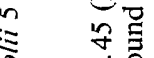

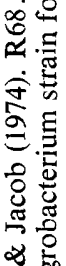

$+++1++1+11++++++111+$

为

要焉

$\widehat{\overrightarrow{\mathrm{F}}} \stackrel{\text { ț }}{\mathrm{E}}$

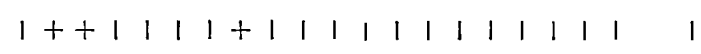

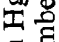

竚苯

药兽

范

芒

용

똥

㝋至

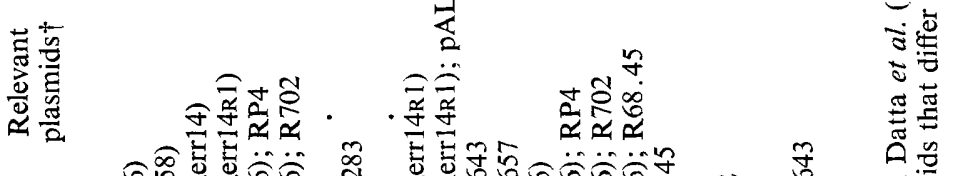

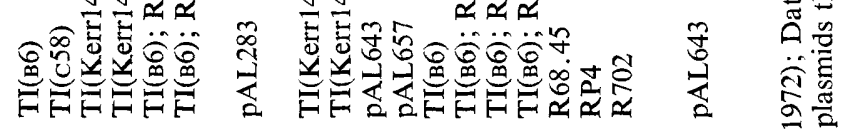

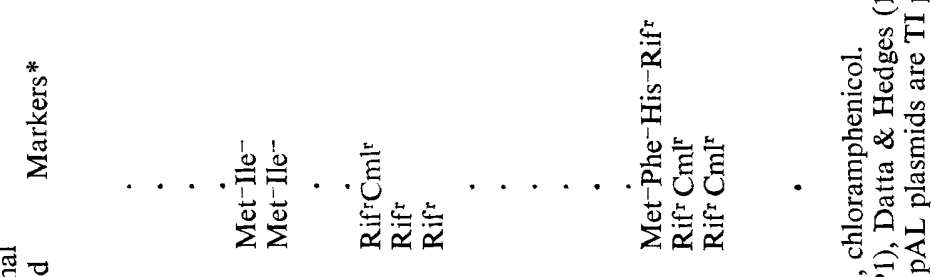

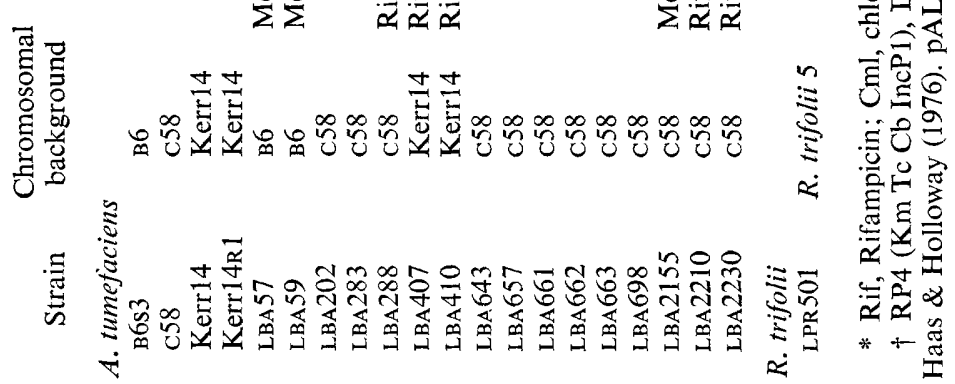


Table 2. Appearance of colonies on BTB medium containing various nitrogen sources

\begin{tabular}{|c|c|c|c|c|}
\hline \multirow[b]{2}{*}{ Nitrogen source } & \multicolumn{4}{|c|}{ Strain* } \\
\hline & c58 & LBA202 & LBA 283 & LBA661 \\
\hline Ammonium sulphate & or.-yellow & or.-yellow & or.-yellow & or.-yellow \\
\hline Potassium nitrate & blue & blue & blue & blue \\
\hline Arginine & or.-yellow & or.-yellow & or.-yellow & or.-yellow \\
\hline Octopine & translucent $\dagger$ & translucent & or.-yellow & or.--yellow \\
\hline Octopinic acid & translucent & translucent & or.-yellow & or.-yellow \\
\hline Lysopine & yellow & translucent & or.-yellow & or.-yellow \\
\hline Nopaline & or.-yellow & translucent & or.-yellow & translucent \\
\hline
\end{tabular}

or.-yellow, Orange-yellow.

* Strain c58 utilizes nopaline; LBA661 utilizes octopine; LBA283 utilizes both octopine and nopaline; LBA202 utilizes neither of them.

$\dagger$ Orange-yellow colonies of spontaneous octopine-utilizing mutants appeared.

Detection of guanidines in tumours was as described by Schilperoort \& Bomhoff (1975).

Uptake of octopine by the bacteria. Cultures grown overnight in MM in the presence or absence of octopine or nopaline, as described by Klapwijk et al. (1977), were diluted with an equal volume of similar fresh medium and incubated for another $150 \mathrm{~min}$. Bacteria were then sedimented, washed with $\mathrm{MM}-\mathrm{N}$ (minimal medium from which the nitrogen source was omitted) and resuspended in $\mathrm{MM}-\mathrm{N}$ at $5 \times 10^{8}$ bacteria $\mathrm{ml}^{-1}$. $\left[{ }^{3} \mathrm{H}\right]$ Octopine $\left(2.9 \mu \mathrm{Ci}\right.$ in $\left.5 \mu \mathrm{l}, 675 \mu \mathrm{Ci} \mu \mathrm{mol}^{-1}\right)$ was then added to $0.5 \mathrm{ml}$ of this bacterial suspension. After $6 \mathrm{~min}$, a sample $(250 \mu \mathrm{l})$ was diluted with $5 \mathrm{ml} 0.9 \% \mathrm{NaCl}$, filtered on a membrane filter ( $23 \mathrm{~mm}$ diam.; $0.45 \mu \mathrm{m}$ pore size) and washed with $20 \mathrm{ml} 0.9 \% \mathrm{NaCl}$. Filters were dried, immersed in toluene containing $0.4 \%(\mathrm{w} / \mathrm{v}) 2,5$ diphenyloxazole and counted in a liquid scintillation spectrometer.

Chemicals. $\mathrm{D}(+)$-Octopine and $\mathrm{D}(+)$-octopinic acid were from Sigma; lysopine, nor-octopine and $\mathrm{D}$ nopaline were from Dr B. Lejeune (Orsay, France), Dr J. Tempé (Versailles, France) and Dr M. van Montagu (Brussels, Pelgium), respectively. Homo-octopine, desmethylhomo-octopine and $\left[{ }^{3} \mathrm{H}\right]$ octopine were synthesized as described by Klapwijk et al. (1977).

\section{RESULTS}

\section{Indicator medium}

Bomhoff (1974) found that agrobacteria cultured in liauid medium with glucose as a carbon source and octopine as a nitrogen source acidified the medium. By incorporating a $\mathrm{pH}$ indicator in such a medium, we found differences in acid production between octopineutilizing bacteria and non-utilizers if a minimal concentration of phosphate $\left(\mathrm{K}_{2} \mathrm{HPO}_{4}\right.$, $0.09 \mathrm{~g} \mathrm{l}^{-1}$ ) was present (see Methods). Bromothymolblue was the most suitable indicator, although bromocresolpurple, alizarin, cresol red and neutral red could be used instead. On green bromothymolblue (BTB) plates, octopine-utilizing bacteria formed orange-yellow colonies, while those of non-utilizers remained translucent. Colonies of some non-utilizers became yellow, but only after incubation for more than $5 \mathrm{~d}$. Even then their colour was different from that of octopine-utilizing colonies.

When $10^{9}$ nopaline-degrading bacteria were plated on this medium, a few orange-yellow colonies became visible in a layer of confluent growth; these were mutants capable of degrading both octopine and nopaline, as isolated previously by Petit \& Tempé (1975) and Hooykaas et al. (1977).

Octopine could be replaced by other nitrogen sources in BTB medium (Table 2). Whenever a strain could utilize the nitrogen source present (with the exception of nitrate), acid was produced. Colonies formed on medium containing nitrate were blue, indicating alkali production. Octopine was the best nitrogen source for the selection of strains harbouring octopine plasmids; results with octopinic acid and lysopine were less clear, although degradation of these three compounds is linked (Klapwijk et al., 1976; Klapwijk et al., 1977). Nopaline-utilizing strains produced yellow colonies on lysopine, so presumably lysopine is metabolized by such strains, as previously shown by Lippincott et al. (1973). 


\section{Table 3. Transfer of TI plasmid mediated by $R$ plasmids}

Crosses were performed as described in Methods. Total counts were determined by plating after crossing. Recipient strains never segregated spontaneous mutants forming orange-yellow colonies on BTB medium. Donor strains reverted to rifampicin resistance at a frequency of $9 \times 10^{-8}$; this number was subtracted from the calculated transfer frequencies.

\begin{tabular}{|c|c|c|c|c|c|}
\hline Cross* & $\begin{array}{l}\text { No. of or.- } \\
\text { yellow colonies } \\
\text { on BTB }+ \text { Rif } \dagger\end{array}$ & $\begin{array}{l}10^{-6} \times \text { total no. } \\
\text { of Rif }{ }^{r} \text { bacteria }\end{array}$ & $\begin{array}{l}\text { Frequency of } \\
\text { transfer of } \mathrm{TI} \\
\text { plasmid per } \\
\text { recipient }\end{array}$ & $\begin{array}{l}\text { Frequency of } \\
\text { transfer of } R \\
\text { plasmid per } \\
\text { recipient }\end{array}$ & $\begin{array}{l}\text { TI plasmid } \\
\text { mobilization } \\
\text { frequency }\end{array}$ \\
\hline LBA $661 \times$ LBA 288 & 8 & 110 & $<10^{-8}$ & 一 & - \\
\hline LBA $662 \times$ LBA 288 & 33 & 104 & $2 \times 10^{-7}$ & $2 \times 10^{-2}$ & $1 \times 10^{-5}$ \\
\hline LBA $663 \times$ LBA 288 & 512 & 132 & $4 \times 10^{-6}$ & $2 \times 10^{-2}$ & $2 \times 10^{-4}$ \\
\hline LBA $698 \times$ LBA 288 & 18 & 119 & $6 \times 10^{-8}$ & $1 \times 10^{-2}$ & $6 \times 10^{-6}$ \\
\hline LBA $662 \times$ LBA 288 (at $37^{\circ} \mathrm{C}$ ) & 47 & 5 & $7 \times 10^{-6}$ & $2 \times 10^{-1}$ & $4 \times 10^{-5}$ \\
\hline LBA $663 \times$ LBA 288 (at $37^{\circ} \mathrm{C}$ ) & 130 & 3 & $4 \times 10^{-5}$ & $3 \times 10^{-1}$ & $1 \times 10^{-4}$ \\
\hline LBA $662 \times$ LBA 2230 & 17 & 123 & $6 \times 10^{-8}$ & $4 \times 10^{-4}$ & $2 \times 10^{-4}$ \\
\hline LBA $663 \times$ LBA 2210 & 29 & 138 & $1 \times 10^{-7}$ & $2 \times 10^{-4}$ & $5 \times 10^{-4}$ \\
\hline
\end{tabular}

* Strain LBA288 is a rifampicin-resistant cured derivative of c58. LBA661 is a cured derivative of c58 into which TI(B6) was introduced by transformation. LBA662, LBA663 and LBA698 are derivatives of LBA661 carrying, respectively, RP4, R702 and R68.45. LBA2210 and LBA2230 are derivatives of LBA288 carrying, respectively, $\mathrm{RP} 4$ and $\mathrm{R} 702$

$\dagger$ BTB medium (with octopine as nitrogen source) containing rifampicin to prevent growth of donor cells.

\section{Mobilization of TI plasmids by $R$ plasmids}

We previously reported mobilization of the TI plasmid by the R plasmid RP4 (Hooykaas et al., 1977), but were not able to calculate the transfer frequency because of lack of a proper selective medium. We have now determined mobilization frequencies from $\mathrm{R}^{+}$ rifampicin-sensitive donor strains to a rifampicin-resistant recipient strain not containing a TI plasmid by plating dilutions of the conjugation mixture on BTB plates, in which rifampicin was incorporated to prevent the growth of donor cells. Orange-yellow colonies that appeared were checked for utilization of octopine in liquid medium, for virulence, for resistance to rifampicin and for $\mathrm{R}$ plasmid markers (Table 3 ). No orange-yellow colonies developed when the recipient alone was plated, and only a few did so when the donor alone was plated. The latter probably represent spontaneous rifampicin-resistant mutants. Transfer frequencies were calculated by subtracting this number from the total number of orange-yellow colonies observed. While no transfer of the TI plasmid was observed from $\mathrm{R}^{-}$- strains, we found transfer from donor strains carrying RP4, R702 or R68.45. R plasmid transfer and mobilization of the TI plasmid were not inhibited at $37{ }^{\circ} \mathrm{C}$. However, when the recipient bacterium already harboured a $P$ plasmid, the frequency with which the $R$ plasmid was transferred dropped significantly, indicative of entry-exclusion of the $R$ plasmid. The frequency with which the TI plasmid was transferred was lower, but the calculated mobilization frequency per $\mathbf{R}$ plasmid transferred was somewhat higher.

\section{Effect of selected amino acids and organic acids on the transfer of TI plasmid in the absence of octopine}

Transfer of the TI plasmid was not observed from $\mathrm{R}$ - donor strains on either NB or MM, but addition of octopine, octopinic acid or lysopine to MM resulted in the transfer of TI plasmids. Addition of octopine or octopinic acid to different final concentrations $(100,500$ or $1000 \mathrm{mg} \mathrm{l}^{-1}$ ) had no effect on the frequencies or transfer. As only a limited amount of lysopine was available, different concentrations were not tested.

Addition of analogues of octopine - nor-octopine, homo-octopine or desmethylhomooctopine (structural formulae in Fig. 1) - to MM did not induce plasmid transfer, nor did other amino acids, including $\mathrm{D}$ - and L-alanine, L-arginine, L-lysine and L-ornithine (at 


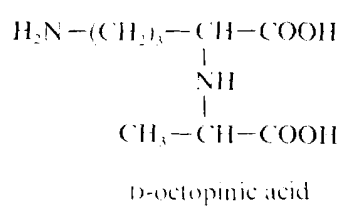<smiles>CCCC(NC(C)C(=O)O)C(=O)O</smiles>
D-Iysopine<smiles>C=CNCCC(NC(C)C(=O)O)C(=O)O</smiles><smiles>C=C(N)NCC(NC(C)C(=O)O)C(=O)O</smiles><smiles>N=C(N)NCC(NCC(=O)O)C(=O)O</smiles><smiles>N=CNCC(N)C(=O)O</smiles>

noroctopine<smiles>N=C(N)NCC(NCC(=O)O)C(=O)O</smiles>

desmethylhomo-octopine<smiles>N=CNCCC(NC(C=CC(=O)O)C(=O)O)C(=O)O</smiles>

b-nopaline

Fig. 1. Structural formulae of the amino acid derivatives.

100 or $\left.1000 \mathrm{mg} \mathrm{l}^{-1}\right)$, or the organic acids pyruvate, citrate, malate, succinate and 2-oxoglutarate (at 100 or $1000 \mathrm{mg} \mathrm{l}^{-1}$ ). On media containing L-arginine as well as pyruvate, no transfer of the TI plasmid was observed.

\section{Effect of metabolites on the transfer of TI plasmids in the presence of octopine}

No transfer of TI plasmids was detected on NB or on NB containing octopine; thus there are probably inhibitors of transfer present in NB. To investigate this, we studied the effect of various metabolites on the transfer of TI plasmids on MM plus octopine. Amino acids such as $\mathrm{L}$ - and $\mathrm{D}$-methionine, $\mathrm{L}$-cysteine and $\mathrm{L}$-cystine (all at $50 \mathrm{mg} \mathrm{l}^{-1}$ ) completely inhibited transfer, whereas L-alanine, L-arginine, L-asparagine, L-aspartic acid, L-citrulline, L-glutamine, L-glutamic acid, glycine, L-histidine, L-isoleucine, L-leucine, L-lysine, L-ornithine, L-phenylalanine, L-proline, L-serine, L-threonine, L-tryptophan, L-valine and L-homoserine did not influence it. Glucose could be replaced as a carbon source by xylose, rhamnose, galactose, lactose, citrate, succinate, 2-oxoglutarate, malate or pyruvate.

Since methionine inhibited transfer, we studied whether this compound could also inhibit tumour induction. Bacteria were inoculated in the wound-site of a plant (Kalanchoë daigremontiana) in the presence of methionine $\left(500 \mu \mathrm{g} \mathrm{ml}^{-1}\right)$ and during the next $3 \mathrm{~d}$ methionine $\left(500 \mu \mathrm{g} \mathrm{ml}^{-1}\right)$ was inoculated in the wound-site twice a day. Normal tumours developed; thus, unless plant cells have a mechanism for removing methionine very efficiently within a short period of time, methionine does not prevent tumour induction.

\section{Correlation between the regulation of the octopine permease gene and} the transfer genes

Klapwijk et al. (1977) showed that the octopine permease could be induced by octopine, octopinic acid and lysopine, but not by nor-octopine, homo-octopine and desmethylhomo- 
Table 4. Influence of L-methionine on octopine uptake by strain LBA661

Cultures were grown in different media, washed twice and tested for uptake of $\left[{ }^{3} \mathrm{H}\right]$ octopine in the absence or presence of methionine $\left(166 \mathrm{mg} \mathrm{l}^{-1}\right)$, as described in Methods. Strain LBA661 is a cured derivative of $\mathrm{C} 58$ carrying the wild-type TI(B6) plasmid.

\begin{tabular}{|c|c|c|}
\hline & \multicolumn{2}{|c|}{$\left[{ }^{3} \mathrm{H}\right]$ Octopine taken up (c.p.m.) } \\
\hline Culture medium & $\begin{array}{c}\text { Methionine } \\
\text { absent }\end{array}$ & $\begin{array}{c}\text { Methionine } \\
\text { present }\end{array}$ \\
\hline $\mathrm{MM}$ & 646 & not tested \\
\hline $\mathrm{MM}+$ octopine & 4521 & 5184 \\
\hline $\begin{array}{l}\text { MM + octopine } \\
\quad+\text { methionine }\left(50 \mathrm{mg} \mathrm{l}^{-1}\right)\end{array}$ & 6909 & not tested \\
\hline
\end{tabular}

Table 5. Influence of temperature on transfer of pAL643

Strain LBA643, carrying a TI plasmid 'derepressed' for transfer, was crossed with LBA288, a rifampicin-resistant cured derivative of $\mathrm{C} 58$, at different temperatures.

$\begin{array}{cc} & \text { Transfer frequency } \\ \text { Temperature }\left({ }^{\circ} \mathrm{C}\right) & 1 \times 10^{-2} \\ 22 & 1 \times 10^{-2} \\ 29 & 5 \times 10^{-4} \\ 32 & 6 \times 10^{-6} \\ 34 & <10^{-8} \\ 37 & \end{array}$

octopine. Since transfer of the TI plasmid takes place only in the presence of the first three compounds, it is possible that the transfer and permease genes are regulated by a similar, or the same, regulator gene. We therefore studied the effect of methionine on the octopine uptake system. Methionine did not inhibit uptake of octopine by the cell nor did it prevent induction of the octopine permease gene (Table 4). Thus methionine exclusively inhibits the transfer system.

Six transconjugants from crosses with donor strains lacking an $\mathrm{R}$ plasmid on media without inducer were found to harbour mutant plasmids that were 'derepressed' for transfer. These plasmids were transferable in the absence of inducer; moreover, this transfer was not inhibited by methionine, cysteine or cystine. However, like the wild-type plasmids, they were thermosensitive for transfer (Table 5) and transfer-negative on NB. Five of them had inducible octopine permease genes; in the sixth, these genes were constitutive. A plasmid 'derepressed' for transfer and constitutive for the octopine enzymes (pAL657) has been obtained by insertion of Tn 1 into the TI(B6) plasmid (unpublished results), indicating that the octopine permease and transfer genes may be controlled by the same regulator.

\section{Transfer of an octopine TI plasmid into Kerr 14R1}

Kerr $14 \mathrm{R} 1$ is a derivative of the nopaline-utilizing strain Kerr14 that harbours a TI plasmid from which $12 \mu \mathrm{m}$ of DNA have been deleted (Hernalsteens et al., 1975). This plasmid still carries the nopaline permease gene, since octopine is taken up by the bacterium after induction by nopaline but not octopine (Klapwijk et al., 1977). For octopine uptake, octopine strains require induction by octopine whereas nopaline strains are induced by nopaline.

The octopine plasmid from strain LPR 50l was introduced into Kerr14R1 by conjugation. The properties of the transconjugant (LBA410) are compared with those of reference strains in Table 6. Strain LBA410 organisms were able to transport octopine after induction by octopine or nopaline; thus LBA410 probably carries both the octopine TI plasmid and the Kerr14R1 plasmid. Since there was no selection for the Kerr14R1 plasmid, this observation suggests that the deleted plasmid is compatible with the octopine plasmid. 
Table 6. Properties of $\mathrm{LBA} 410$ and various reference strains

\begin{tabular}{|c|c|c|c|c|c|}
\hline Property & Kerr14 & Kerr14R1 & LBA410 & LPR501 & LBA661 \\
\hline \multicolumn{6}{|l|}{ Sensitivity to: } \\
\hline Phage S1 & + & + & + & - & - \\
\hline Phage S2 & - & - & - & - & + \\
\hline Phage S3 & + & + & + & - & - \\
\hline Phage S5 & - & - & - & - & + \\
\hline Phage S6 & + & + & + & - & + \\
\hline Phage S18 & + & + & + & - & - \\
\hline Phage AP1 & + & + & + & - & + \\
\hline Phage LPB51 & - & - & - & + & - \\
\hline Agrocin 84 & + & - & - & - & - \\
\hline Agrocin s 1005 & + & + & + & - & - \\
\hline \multicolumn{6}{|l|}{ Exclusion of:* } \\
\hline Phage S18 & + & - & - & $\dagger$ & $\dagger$ \\
\hline Phage AP1 & + & - & + & $\dagger$ & + \\
\hline Virulence & + & - & + & + & + \\
\hline Guanidines in tumour & nopaline & & octopine & octopine & octopine \\
\hline Tumour morphology & smooth & & rough & rough & rough \\
\hline Utilization of octopine & - & - & + & + & + \\
\hline Utilization of nopaline & + & - & - & - & - \\
\hline $\begin{array}{l}\text { Utilization when growing } \\
\text { on both octopine and nopaline }\end{array}$ & $\begin{array}{l}\text { octopine and } \\
\text { nopaline }\end{array}$ & - & octopine & octopine & octopine \\
\hline \multicolumn{6}{|c|}{ Uptake of octopine after growth on: } \\
\hline MM & - & - & - & - & - \\
\hline MM+ octopine & - & - & + & + & + \\
\hline MM+ nopaline & + & + & + & - & - \\
\hline
\end{tabular}

* Phages S18 and AP1 do kill cells containing a TI plasmid, but they only form plaques on hosts lacking a TI plasmid; this phenomenon has been termed 'exclusion'. + , No formation of plaques, indicative of exclusion; - , formation of plaques.

+ Since LPR501 is resistant to both S18 and AP1, exclusion of either of these phages could not be tested. LBA661 is sensitive to AP1 but resistant to S18, so only exclusion of AP1 could be tested.

When the octopine and nopaline permeases were induced by growing LBA410 in the presence of octopine and nopaline, the strain was shown to degrade octopine, but not nopaline (Table 6). So, even when nopaline can enter the cell through its own permease, it is not metabolized by the octopine oxidase; this is indicative of a difference between octopine and nopaline oxidases, since nopaline strains do degrade octopine in the presence of nopaline (Petit \& Tempé, 1975).

Strain LBA410 induced rough tumours containing octopine on Kalanchoë daigremontiana, so the deleted plasmid is not able to influence either tumour morphology or synthesis of guanidines, since these are characters of octopine-utilizing strains. Whereas Kerr 14 excludes phages S18 and AP1 and Kerr14R1 excludes neither of them, strain LBA410 only excluded AP1. Thus, exclusion of phage S18 is probably a marker specific for the TI(Kerr14) plasmid. Exclusion of AP1 is a marker widespread on TI plasmids including TI(B6), TI(C58) and TI(Kerr14) (Hooykaas et al., 1977).

\section{DISCUSSION}

In our experiments we used, where possible, strains with the same chromosomal background to prevent the results being influenced by restriction enzyme processes. One restriction enzyme has already been isolated from Agrobacterium tumefaciens (Roizès et al., 1977).

Our results confirm those of Kerr et al. (1977) and Genetello et al. (1977) who found that octopine is necessary for transfer of octopine TI plasmids. Since transfer of such plasmids only takes place in the presence of octopine, lysopine or octopinic acid, compounds that are known to induce the octopine permease (Klapwijk et al., 1977), it is possible that the transfer genes are controlled by the regulator molecule that also controls the octopine per- 
mease gene. The existence of mutants that no longer need octopine for transfer of the TI plasmid ('derepressed' mutants) but are still dependent on octopine for the induction of the octopine permease shows that transfer of TI plasmids does not require the presence of the permease. These plasmids may carry mutations in the operator region of the transfer genes. Plasmid pAL657 may have become constitutive for the octopine enzymes and derepressed for transfer by insertion of $\operatorname{TnA}$ in a regulator gene that controls both the genes coding for utilization of octopine and the transfer genes.

Sulphur-containing amino acids, including cysteine, blocked transfer, while serine (which is identical to cysteine except for replacement of the sulphur atom by an oxygen atom) did not influence transfer of TI plasmids. The fact that D-methionine was able to inhibit transfer indicates that the amino acids probably do not need to be metabolized to exert their repressive effect. Transfer of plasmids 'derepressed' for transfer was not influenced by methionine, cysteine or cystine. Furthermore neither uptake of octopine nor the induction of the permease was inhibited by methionine. Taken together, these observations suggest that methionine, cysteine and cystine act as (co)-repressors only active on the operator of the transfer genes. Since methionine is a substrate for lysopine dehydrogenase (Otten et al., 1977), methiopine - the methionine analogue of octopine - may be synthesized in crown gall tumours by analogy with the other crown gall amino acids. Whether this molecule will induce or inhibit transfer is a very intriguing question.

Both the wild-type plasmid and the 'derepressed' mutant plasmids were thermosensitive for transfer, as shown by Tempé et al. (1977) for the TI plasmid from a wild-type strain. Transfer occurred equally well at 22 and $29^{\circ} \mathrm{C}$, was reduced at $32^{\circ} \mathrm{C}$, very poor at $34{ }^{\circ} \mathrm{C}$, and did not take place at all at $37^{\circ} \mathrm{C}$. However, for various plant species, tumour induction is reported to be inhibited at temperatures between 28 and $30^{\circ} \mathrm{C}$, whilst no tumours are formed at higher temperatures (Riker, 1926; Braun, 1947, 1950). Thus, while tumour induction is inhibited above $30^{\circ} \mathrm{C}$, transfer of TI plasmids is only slightly affected at this temperature. Using a Mazzard cherry, Deep \& Hussin (1962) found that when inoculated roots were kept at a soil temperature of $35^{\circ} \mathrm{C}$ for $5 \mathrm{~d}$ following inoculation with A. tumefaciens, galls were more numerous and larger than on similar plants kept at $25^{\circ} \mathrm{C}$. This observation indicates that temperature sensitivity of tumour induction is specific for the host plant, suggesting that there is no direct relation between the temperature sensitivity of the tumour induction and that of the (bacterium-bacterium) TI plasmid transfer. The fact that methionine inhibits transfer of TI plasmids, but has no influence on tumour induction, supports this hypothesis.

We thank Dr P. M. Klapwijk for providing materials and for helpful discussions. This work was sponsored by the Netherlands Foundation for Chemical Research (SON) with financial aid from the Netherlands Organization for the Advancement of Pure Scientific Research (ZWO).

\section{REFERENCES}

Bernaerts, M. \& De Ley, J. (1963). A biochemical test for crown gall bacteria. Nature, London 197, 406-407.

BomHoFf, G. H. (1974). Studies on crown gall-a plant tumour. Investigations on protein composition and on the use of guanidine compounds as a marker for transformed cells. Thesis, University of Leiden, The Netherlands.

Bonhoff, G. H., KlaPWiJK, P. M., Kester, H. C. M., Schilperoort, R. A., Hernalsteens, J. P. \& SCHelL, J. (1976). Octopine and nopaline: synthesis and breakdown genetically controlled by a plasmid of Agrobacterium tumefaciens. Molecular and General Genetics 145, 177-181.
Braun, A. C. (1947). Thermal studies on the factors responsible for tumor initiation in crown gall. American Journal of Botany 34, 234-240.

Braun, A. C. (1950). Thermal inactivation studies on the tumor-inducing principle in crown gall. Phytopathology 40, 3.

Chilton, M.-D., Farrand, S. K., Levin, R. \& NESTER, E. W. (1976). RP4 promotion of transfer of a large Agrobacterium plasmid which confers virulence. Genetics 83, 609-618.

Chilton, M.-D., Drummond, M. H., Merlo, D. J., Sciaky, D., Montoya, A. L., Gordon, M. P. \& Nester, E. W. (1977). Stable incorporation of plasmid DNA into higher plant cells: the mole- 
cular basis of crown gall tumorigenesis. Cell 11, 263-271.

DatTA, N. \& Hedges, R. W. (1972). Host ranges of $\mathrm{R}$ factors. Journal of General Microbiology $\mathbf{7 0}$, 453-460.

Datta, N., Hedges, R. W., Shaw, E. J., Sykes, R. B. \& Richmond, M. H. (1971). Properties of an $\mathrm{R}$ factor from Pseudomonas aeruginosa. Journal of Bacteriology 108, 1244-1249.

DeEP, I. W. \& Hussin, H. (1962). Effect of postinoculation temperature on crown gall development on cherry. Phytopathology 52, 360.

Drummond, M. H., Gordon, M. P., Nester, E. W. \& Chilton, M.-D. (1977). Foreign DNA of bacterial plasmid origin is transcribed in crown gall tumours. Nature, London 269, 535-536.

Genetello, C., van Larebeke, N., Holsters, M., DE Picker, A., van Montagu, M. \& Schell, J. (1977). The Ti plasmids of Agrobacterium as sex factors. Nature, London 265, 561-563.

Gordon, M. P., Farrand, S. K., Sciaky, D., Montoya, A., Chilton, M.-D., Merlo, D. \& Nester, E. W. (1978). In Molecular Biology of Plants, Symposium, University of Minnesota, 1976. Edited by I. Rubenstein. New York: Academic Press (in the Press).

HaAs, D. \& Holloway, B. W. (1976). R factor variants with enhanced sex factor activity in Pseudomonas aeruginosa. Molecular and General Genetics 144, 243-251.

HedGes, R. W. \& JACOB, A. E. (1974). Transposition of ampicillin resistance from RP4 to other replicons. Molecular and General Genetics 132, 31-40.

Hernalsteens, J. P., Engler, G., van Larebeke, N., van Montagu, M. \& Schell, J. (1975). Studies on large DNA plasmids of Agrobacterium tumefaciens. Archives internationales de physiologie et de biochimie 83, 368-369.

Hooykaas, P. J. J., KlapwiJk, P. M., Nuti, M. P., SCHILPEROORT, R. A. \& RÖRSCH, A. (1977). Transfer of the Agrobacterium tumefaciens TI plasmid to avirulent agrobacteria and to Rhizobium ex planta. Journal of General Microbiology 98, 477-484.

KEMP, J. D. (1976). Octopine as a marker for the induction of tumorous growth by Agrobacterium tumefaciens strain в6. Biochemical and Biophysical Research Communications 69, 816-822.

KERR, A. (1971). Acquisition of virulence by nonpathogenic isolates of Agrobacterium radiobacter. Physiological Plant Pathology 1, 241-246.

Kerr, A., Manigault, P. \& Tempé, J. (1977). Transfer of virulence in vivo and in vitro in Agrobacterium. Nature, London 265, 560-561.

KlapwiJk, P. M., HoOyKaAs, P. J. J., Kestek, H. C. M., SChilperoort, R. A. \& RörSCH, A. (1976). Isolation and characterization of Agrobacterium tumefaciens mutants affected in the utilization of octopine, octopinic acid and lysopine. Journal of General Microbiology 96, 155-163.

KlapwiJk, P. M., Oudshoorn, M. \& Schilperoort, R. A. (1977). Inducible permease involved in the uptake of octopine, lysopine and octopinic acid by Agrobacterium tumefaciens strains carrying virulence-associated plasmids. Journal of General Microbiology 102, 1-11.
Larebeke, N. van, Genetello, C., Schell, J., Schilperoort, R. A., Hermans, A. K., HernalSteens, J.P. \& VAN Montagu, M. (1975). Acquisition of tumor inducing ability by nononcogenic Agrobacteria as a result of plasmid transfer. Nature, London 255, 742-743.

larebeke, N. van, Genetello, C., Hernalsteens, J. P., De Picker, A., Zaenen, I., Messens, E., van Mon'tagu, M. \& Schell, J. (1977). Transfer of Ti-plasmids between Agrobacterium strains by mobilisation with the conjugative plasmid RP4. Molecular and General Genetics 152, 119-124.

LippincotT, B. B. \& LipPincotT, J. A. (1969). Bacterial attachment to a specific wound site as an essential stage in tumor initiation by Agrobacterium tumefaciens. Journal of Bacteriology 97, 620-628.

LipPincotT, J. A., BeIDERBECK, R. \& LipPincotT, B. B. (1973). Utilization of octopine and nopaline by Agrobacterium. Journal of Bacteriology 116, 378-383.

Lippincott, B. B., Whatley, M. H. \& Lippincott, J. A. (1977). Tumour induction by Agrobacterium involves attachment of the bacterium to a site on the host plant cell wall. Plant Physiology 59, 388390.

Montoya, A. L., Chilton, M.-D., Gordon, M. P., SCIAKY, D. \& Nester, E. W. (1977). Octopine and nopaline metabolism in Agrobacterium tumefaciens and crown gall tumor cells: role of plasmid genes. Journal of Bacteriology 129, 101-107.

Otten, L. A. B. M., Vreugdenhil, D. \& SchilPEROORT, R. A. (1977). Properties of $\mathrm{D}(+)$ lysopine dehydrogenase from crown gall tumour tissue. Biochimica et biophysica acta 485, 268-277.

Petit, A. \& Tempé, J. (1975). Étude du métabolisme des guanidines des tissus de crown-gall par la souche T37 d'Agrobacterium tumefaciens. Comptes rendus hebdomadaire des séances de l'Académie des sciences 281, 467-469.

Petit, A., Delhaye, S., Tempé, J. \& Morel, G. (1970). Recherches sur les guanidines des tissus de crown gall. Mise en évidence d'une relation biochimique spécifique entre les souches d'Agrobacterium tumefaciens et les tumeurs qu'elles induisent. Physiologie Végétale 8, 205-213.

RIKER, A. J. (1926). Studies on the influence of some environmental factors on the development of crown gall. Journal of Agricultural Research 32, 83-96.

Roiż̀, G., Patillon, M. \& Kovoor, A. (1977). A restriction endonuclease from Agrobacterium tumefaciens. FEBS Letters 82, 69-70.

SCHILPEROORT, R. A. (1969). Investigations on plant tumors. Crown gall. On the biochemistry of tumor induction by Agrobacterium tumefaciens. Thesis, University of Leiden, The Netherlands.

Schilperoort, R. A. \& BomhofF, G. H. (1975). Crown gall: a model for tumor research and genetic engineering. In Genetic Manipulations with Plant Material, pp. 141-162. Edited by L. Ledoux. New York: Plenum Press.

Tempé, J., Petit, A., Hosters, M., van Montagu, M. \& Schell, J. (1977). Thermosensitive step associated with transfer of Ti-plasmid during conjugation: possible relation to transformation 
in crown gall. Proceedings of the NationalAcademy of Sciences of the United States of America 74, 2848-2849.

Watson, B., Currier, T. C., Gordon, M. P., Chilton, M.-D. \& Nester, E. W. (1975). Plasmid required for virulence of Agrobacterium tumefaciens. Journal of Bacteriology 123, 255-264.

Whatley, M. H., Bonwin, J. S., LipPincotT, B. B.
\& LipPINCOTT, J. A. (1976). Role for Agrobacterium cell envelope lipopolysaccharide in infection site attachment. Infection and Immunity 13, 1080-1083.

ZaEnen, I., van LAREBEKe, N., Teuchy, H., vaN Montagu, M. \& Schell, J. (1974). Supercoiled circular DNA in crown gall inducing Agrobacterium strains. Journal of Molecular Biology 86, 109-127. 